\title{
Determinants of Female Students' Involvement in Communicative English Skills Classroom Instruction with Particular Reference to Wolaita Sodo University, Ethiopia
}

\author{
Faskal Faranso Faltamo \\ Faculty of Social Science and Humanities, Department of English Language and Literature, Wolaita Sodo \\ University, Sodo, Ethiopia
}

\begin{abstract}
Any successful classroom instruction at all level of education demands students' involvement in it. That is, the students must devote their time and effort for successful teaching-learning process. In this regard, the involvement of female students in their University level education is therefore taken as integral part of quality education. Hence, this study was aimed to analyze female students' involvement in communicative English Skills classroom instruction with particular reference to Wolaita Sodo University, Ethiopia. To achieve the intended goal, descriptive research design with the data qualitative methods of data collection was employed. The data were collected from 352 female students who were selected by using convenience sampling technique. Results of the study showed that significant numbers of female students faced lots of challenges during communicative English Skills classroom instruction. The major determinants for their involvement includes poor English proficiency, their attitude towards the course, knowledge and skill gaps, lack of motivation to involve, the male students' dominance, lack of interest to involve, and socio-cultural and economic factors. Based on the findings of the study, it is concluded that female students' involvement in learning the course was very low. Therefore, it is recommended that concerned bodies should give attention for female students' learning through their classroom involvements to improve the female students' learning.
\end{abstract}

Keywords: Determinant, Involvement, academic achievement, classroom Instruction

DOI: $10.7176 /$ RHSS/9-11-09

Publication date:June $30^{\text {th }} 2019$

\section{Background of the study}

Active involvements of students in EFL classroom instructions play vital role in effective teaching learning processes. The term engagement or involvement encompasses behavioral, emotional, and cognitive dimensions which together are necessary in successful learning [1]. Then, those who effectively engaged in the process tend to have better academic achievement compared to students who do not participate [2]. In the context of English as a Foreign/Second Language (EF/SL) teaching and learning, students' verbal participation or engagement is essentially important [3]. It is also certain that students' engagement in classroom involves not only their verbal participation, but also some other aspects. According [4] students classroom involvements include the amount of personal time a student devotes to learning in college, and the degree of personal effort or energy (mental and physical) that a student puts into the learning process. The overall engagements the students in such activity make the classroom instruction effective and improve the students learning at large. In this regard, the involvement of female students in teaching learning process at higher institutions is very important in dynamics of their learning.

Despite, female EFL learners' enrolment as well as their involvement in Ethiopian higher institutions classroom is very poor. Though they attend the same class as their male counter parts for every University course, they have played little role in classroom activities. It should be note that female students face many challenges including their perception that they cannot do what females wish to do by their own because they are female.

More specifically, teaching communicative English skills course at Ethiopian Universities aimed to develop students' language skills to make the students ready for learning other courses. However, the female students' involvement in the course was insufficient. Hence, the researcher conducted this study to assess the determinants of female students' involvement during communicative English skills classroom instructions at Wolaita Sodo University.

\section{Statement of the problem}

Female students face different challenges when learning at Ethiopian higher institutions. According to [5] the factors affecting female students' education in Ethiopian higher institutions are Personal Related Factors, University Related Factors, Academic Related Factors, and Economic Related Factors. And, this previous study was focused on general overview of factors hindering female students' achievements at Ethiopian higher institutions.

Again, [6] analyzed determinants of female students' academic achievement at Bahirdar University and 
come up with finding that 17 types of problems that are categorized under four themes affected female students learning. These themes are the Personal related factors, University related factors, and Academic related factors. However, current study specifically focused on the challenges that affect female students' involvement in communicative English skills classroom instruction.

Teaching Communicative English as common course for students whose major field is other than English language focused on improving the students' English skills as well as their academic achievement through active classroom involvement. In line with this, [4]confirmed that to maximize success in college, students need to be active agents in the learning process, not passive sponges or spectators. Despite, the participation of students' in general and female student's involvement in particular was very low during communicative English skills classroom instructions.

By taking the above scholars idea and the researchers personal observation regarding the problems of female students' in to account, the researcher was highly concerned to assess the problems from its grass root level. Hence, the main focus of current study was analysis of the factors that affected female students' involvement during communicative English skills course classroom instruction with particular reference to Wolaita Sodo University, Ethiopia.

\section{Objectives of the study}

\subsection{General objective}

The main objective of this study was assessing female students' involvement in Communicative English Skills classroom instruction with particular reference to Wolaita Sodo University.

\subsection{Specific objectives}

The specific objectives of this study are:-

- $\quad$ To identify factors that affect female students' involvement in communicative course.

- $\quad$ To analyzing the factors that affect their involvement in the course.

- $\quad$ To suggest possible solutions to improve the students' involvement in the course.

\section{Significance of the study}

The findings of this study believed to have various significances. It is the fact that the course communicative English is base to learn other subjects effectively because it mainly focused on developing students English language skills. Further, it prepares students to be ready for learning other courses effectively. In this regard, this study was believed to boost female students' involvement by critically analyzing the factors. It is also believed that their academic achievement would be improved as their classroom involvement increased in any other courses. Consequently, those female students who take the course communicative English skills become successful in their learning.

\section{Delimitations of the study}

This study was conducted at Wolaita Sodo University in Ethiopia. It focused on female students who learnt Communicative English Skills course in first semester of their freshman year. The main focus of the study was improving female students' involvement in Communicative English Skills course to improve their academic achievement.

\section{Research Methodology}

\subsection{Research Design}

The focus of current study was analysis of factors affecting female students' involvement in Communicative English skills classroom instruction at Wolaita Sodo University. To achieve the intended objective, Descriptive research design was employed. This research design allowed the researcher to use qualitative and quantitative methods of data collection.

\subsection{Target populations of the study}

Total of 352 female students who learnt communicative English Skills course during first semester of 2018/19 academic year were selected as representative for whole population. The students were selected from 12 departments at Wolaita Sodo University.

\subsection{Sample and sampling technique}

All Students of Wolaita Sodo University were populations of this study. However, the researcher took portion of the students as the representatives of whole population. Accordingly, two sampling techniques were employed for this study. First, simple random sampling method was employed to select the departments from which the participants of the study were selected. Hence, twelve departments were selected randomly so as to avoid bias. 
Secondly, convenience sampling technique was employed to select participants of the study across the departments. Since the numbers of female students were unevenly distributed in each department, the researcher took available amounts of female students from each department. Therefore, total of 352 female students from twelve departments were by convenience sampling method.

\subsection{Instruments of data collection}

Open-ended Questionnaire, interview, and non-participant observation were used as tools of data collection for this study. Thus, totals of 352 questionnaires containing ten open-ended questions were distributed to the students. Besides, eight female students out of total target populations were participated in interviewing. Interviews were conducted in the language of the interviewees' preference (in this case English or Amharic language). Finally, whole populations of the study were participated in classroom observations where the researcher visited actual teaching- learning processes in the classroom. The reason for using these three data gathering tools was triangulating the reliability and/or validity of the results obtained through each instrument.

\subsection{Methods of Data analysis}

Qualitative method of data analysis was used to describe results obtained through open-ended questionnaire, interview, and classroom observations. These Qualitative data were analyzed through describing and expressing the results verbally in statement form. Based on results of the study, findings were drawn and conclusions were reached.

\section{Discussions and interpretations of the data}

The focus of this study was analysis of determinant of female students' involvements in communicative English skills classroom with particular reference to Wolaita Sodo University. The data was collected from 2018/19 batch fresh entrant female students of Wolaita Sodo University. Qualitative method of data analysis was employed. The results obtained from the study were discussed and presented as follows.

Current study showed that Communicative English Skills as common course has been offered at Ethiopian higher institutions including Wolaita Sodo University. Since it is a skill course, Communicative English is offered to improve the students' English language skills through their involvement. However, it was identified that the level of female students' participation during communicative English skills class was low. Hence factors that hindered involvement of female students in the course are:-

\subsection{Lack of English proficiency}

Proficiency in instructional languages is very important to become successful via learning in it. In this regard, proficiency in English language is far more important for students who learn it as second or foreign language. The reason is that these students proficiency in it is assumed to be low. For instance, Ethiopian students learn English as foreign language because they are assumed to have problems in understanding it effectively. In this regard, most of female students in Ethiopian higher institutions particularly at Wolaita Sodo University are suffering from lack of English Proficiency.

Hence, teaching communicative English as common course for such students is aimed to fill such gaps by improving their involvement during its classroom instructions. However, open-ended questionnaire results revealed that the involvement of female students in learning the course is very low because they have problem of English. It was also observed that majority of the participants were faced challenges to involve in classroom activities though few of them managed it with difficulties in grammar, vocabulary, and pronunciations. The students also reported that they were not participating in any classroom activities because they have problems in the skills required to accomplish the tasks. The result obtained from classroom observation confirmed that the students were failed to speak, write, read, and listen English pronunciations properly. On other hand, the students' response indicated that they were willing to take part in the course but they have language problems.

The study also revealed that the students' lack of involvement in the course was emanated from their lack of specific skill that is required to perform the task. For instance, some students told the researcher that they did not participate in debate because they have problem in English speaking to do so. Again, some other students also reported that they are less proficient in listening because they have no more understand their instructors talk. Further, the students were also not good at grammar and expressing their ideas in writing. The reason for the students' failure in understanding classroom talks as well as writing in English was effective writing and speaking English demands the students' competence in grammar and vocabulary knowledge. When the students lack those skills, they face challenges in using the language effectively. Thus, it is no doubt that low proficiency in English language affected the involvement students in the course though they were willing to participate.

\subsection{Attitude towards the course}

Learners' attitudes are very significant for classroom involvement and/or participation in EFL classes. 
Communicative English was not major course for the students who participated in this study. It was supportive or common course for them. It was mainly focused on developing students' English language skills since every course they learn was delivered in English. However, the students did not give equal attention to the course as their major courses. They give priority to master their major course(s) than communicative English skills. The responses obtained through open-ended questionnaire revealed that the students were less interested to participate while learning the course because they thought that language skill is simply developed through practice than learning it in class. For this reason, they simply attended the course without any involvement because it was mandatory to take it in order to fulfill the requirements of the university.

After all, the students' focus here was simply getting grades after the end of semester than improvements in their English skills. Contrary to this, it was observed that these students were never missing the classes and the lessons taught in the class though they never take part in teaching-learning processes. Interview results also showed that the reason for students regularly attend the class was simply not to miss attendance as well as the class works if any. In simple words, they perceived learning communicative English course as waste of their time because it was not their major course and would not help them after graduation as a profession.

\subsection{Knowledge and skill gaps}

[7]'asserts that female students may not participate in class because of their own personal fears of feeling inadequate in front of others'. Knowledge gap is the major cause for the students' lack of involvement while learning communicative English skills course in classroom. That is, not all the students were equally competent in understanding what they learn in class because the subject matter dealt in the course was difficult to grasp. The results obtained through interview were confirmed that majority of the students did not understand what their instructors teach them in English. In addition to this, observation results showed that most of the students were low achievers in the course as well as other courses they learnt. It was also clear from the above result was that the students lack of involvement in communicative English skills classroom was developed from lack knowledge in the subject matter.

Besides, the study revealed that the students have unfamiliarity of the skills needed to participate in classroom. Interview result showed that Even if the students were willing to get involved in the course, they faced problems of experience in participating different tasks given by their instructors. For this reason, most of the students were less motivated to contribute their part during communicative English skills course classroom instructions. Overall observation revealed that such students were shy, not motivated to participate, hesitate in their potential to use English, and unwilling to take parts in teaching learning processes. In fact, there were very clever female students in each department where this study was conducted.

\subsection{Lack of motivation}

It was found out that the students were not motivated to learn Communicative English Skills course. The responses obtained from questionnaire results indicated as the students' motivation to learn the course deceased; their level of participation in its instruction was also decreased. Whereas motivated students tend to engage in activities that they believe will help them learn, unmotivated students are not able to be systematic in making an effort in learning, as are motivated students [8].

The interview result further indicated the factors that affected the students' involvement in the course. First, their belief towards the course as not important as major courses since it is skill course. Second, they felt it as the just bridge course and not integral part of their profession. Besides, encouragements from the instructors, inconvenient learning environment, and carelessness were further factors affecting female students' involvements during communicative English classroom instruction.

\subsection{Male students' dominance}

Current study indicated that boys dominated communicative English skill classroom tasks than female students. For this reason, the Female students in the class have got unequal opportunity to participate in any activities. Because of male students dominate the class; the instructors were never mind female students less participation in their course. Despite, it was observed that few female students were struggling to involve in it though they were dominated by male students.

The students also reported that they were dominated not only by male students but also most of their communicative English teachers were males whose concern towards female students' classroom involvement was lower than female instructors. It is also argued in this case that Teachers give more attention to boys than girls and boy involves more than the girls [9]. This showed that the class with male instructors and a majority of male students' dominance is unfavorable for female involvement. The students further elaborated that female instructors understand the conditions of female students learning more than males and motivate them to be involved. In this case those students whose communicative English instructors were females confirmed their satisfaction as they were taught by females. Female students tend to participate more in courses led by a female 
professors and the reverse is true [10]. Further, the researcher also observed that the level of female students' involvement was higher than that of male instructors.

\subsection{Lack of interest}

It is wrong to judge that all female students who do not participate in communicative English skills classroom are lazy. However, they may not be interested to participate for their own reason. The study showed that there were most brilliant female students who were not participating while learning communicative English skills course. Those students responded during interviewing that classroom involvement was less important for them because they did not want to be exposed so as to learn the lesson with deep understanding of it. Therefore, they preferred silent learning with concentration on understanding the lesson than thinking about when and how to participate. Their focus was not in the involvement but understanding the concepts being taught. On other hand, some female students were careless and they did not want to participate in any classroom activities. The researcher realized these situations during classroom observation as such students did not want to get chances even if they were allowed to participate. Thus, the students' reluctance in either of the above ways greatly hindered their involvement in the course.

\subsection{Socio-cultural and economic factors}

As the interview results indicated that most of the students were economically poor and felt uncomfortable to take part in the course. The reason was such students worry about their protocols equally as their education because they are female. Despite, it was observed that there were females struggling regardless of their poor economic status. Besides, the students pointed out that the cultural view of the society in which they were grownup has equal impact on their classroom involvement as their economic status. That means, females are portrayed as shy in most Ethiopian cultures and do not encouraged equally as boys in every aspects of life. Therefore, the culture students' grownup hindered their freedom to involve in classroom. Moreover, these students were also socially biased in their culture as they have limited roles to play in the society. For instance, it is indignity for girls to play or speak with boys anywhere because such girls are given bad names such as prostitutes. Hence, classroom involvement becomes very challenging for such students because they do not have familiarity in sharing ideas with large audience like classrooms.

\section{Finding of the Study}

Communicative English, the skill course, has been offered as common course for undergraduate students at Wolaita Sodo University. It was offered during first semester of freshman year aiming to improve students English language skills. Despite, Findings of the study showed that female students' involvement in its instruction was very low. There were different factors affected female students not to involve in the tasks given by their instructors. The major ones among other factors are English proficiency, attitude towards the course, knowledge and skill gaps, lack of motivation, male students dominance, lack of interest, and socio-cultural and economic were identified as factors that hindered female students' involvement in the course. It was also indicated that female students were discouraged to take part in the course for perceiving it simply as bridge or common course.

\section{Conclusions}

Based on the findings of the study it is concluded that female students' involvement in Communicative English skill course was very poor. It was influenced by the students' poor level of English proficiency, their attitude towards the course, knowledge and skill gaps, lack of motivation to involve, male students' dominance, lack of interest to involve, and socio-cultural and economic factors. In general, Communicative English skill as common course was less studied by female students. Therefore, it is recommended that instructors and other concerned bodies should give attention for female students' learning and their classroom involvements to improve their learning.

\section{References}

- $\quad[1]($ Fredericks,J.A.,Blumenfeld,P.C.,\&Paris,A.H.(2004).Schoolofengagement:Potentialoftheconcept,stat eoftheevidence.ReviewofEducationalResearch,74(1),59-109.

- [2](Liu, M. (2005). Reticence in Oral English Language Classrooms: A Case Study in China. TESL Reporter, 38(1), 1-16.

- [3](Dawit Tesfaye Abebe and Demis G/Tsadik Deneke, (2015). Causes of Students' Limited Participation in EFL Classroom:Ethiopian Public Universities in Focus. International Journal of Educational Research and Technology, P-ISSN 0976-4089; E-ISSN 2277-1557; IJERT: Volume 6 [1] March 2015: 74-89.

- $\quad$ [4](Cuseo, J., (2010). What All First-Year Students Should Know: The Most Potent, Research-Based 
Principles of College Success. Excerpted and adapted from the following source: Cuseo, J., Fecas,V.S.,\& Thompson,2007. A thriving in college \& beyond: research- based strategies for academic success \&personal development. Dubuqeu, IA: Kenall/Haunt.

- $\quad$ 5](Aemiro Tenaw, (2018). Factors Affecting the Academic Performance of Female Students at Higher Education in Ethiopia. Global Journal of Human-Social Science: G Linguistics \& Education; Volume 18 Issue 2 Version 1.0 Year 2018. Online ISSN: 2249-460x\& Print ISSN: 0975-587X. Double Blind Peer Reviewed International Research Journal.

- $\quad[6]$ (Yeshimebrat Mersha, Alemayehu Bishaw and Firew Tegegne, (2013). Factors Affecting Female Students' Academic Achievement at Bahir Dar University. CICE Hiroshima University, Journal of International Cooperation in Education, Vol.15 No.3 (2013) pp.135 148.

- $\quad$ [7](Rocca, A, K. (2010) Student Participation in the College Classroom: An Extended Multidisciplinary Literature Review. Communication Education. 59(2), 185-213.

- $\quad$ [8](Tomoharu Takahashi, (2018). Motivation of students for learning English in Rwandan Schools. Issues in Educational Research, 28(1), 2018.

- $\quad$ [9](Sunderland, J. (ed.) 1994. Exploring gender: questions and implications for English language education. New York: Prentice Hall.

- $\quad[10]$ (Bina Nayee, (2015). Why Should We Care About The Gender Difference in Classroom Participation? SPICE | Philosophy, Politics, and Economics Undergraduate Journal; Volume 10, 2015. 